\title{
Faktor-Faktor yang Mempengaruhi Remaja Putri Melakukan Pernikahan Dini di Kemukiman Lambaro Angan Kabupaten Aceh Besar tahun 2017
}

\author{
Factors Affecting Young Women Conduct Early Marriage in Lambaro Angan \\ Settlement in Greater Aceh District in 2017
}

\author{
Chairanisa Anwar*1, Ernawati \\ ${ }^{1}$ Program Studi D-IV Bidan Pendidik, Fakultas Ilmu Kesehatan, Universitas Ubudiyah Indonesia, Banda Aceh, Indonesia \\ ${ }^{2}$ Program Studi D-IV Kebidanan, Politekhnik Kesehatan Kemenkes Aceh, Banda Aceh, Indonesia
}

*Korespondensi Penulis: chaira.anwar@uui.ac.id

\begin{abstract}
Abstrak
Jumlah kasus pernikahan dini di Indonesia mencapai 50 juta penduduk dengan rata-rata usia perkawinan 19.1 tahun. Sepertiga dari jumlah pernikahan didata dilakukan oleh pasangan di bawah usia 16 tahun. Data dari KUA lambaro Angan Kabupaten Aceh Besar tahun 2016 dari 120 orang pasangan yang menikah, tercatat 24 (20\%) orang pasangan yang menikah dini. Tujuan penelitian ini untuk mengetahui faktor-faktor yang mempengaruhi remaja putri melakukan pernikahan dini di Kemukiman Lambaro Angan Kabupaten Aceh Besar.Jenis penelitian ini bersifat analitik dengan pendekatan crossectional. Sampel dalam penelitian ini berjumlah 68 orang dengan teknik stratisfied random sampling. Pengumpulan data dilakukan dengan membagikan kuesioner kepada pasangan yang telah menikah mulai periode November 2016 sampai Januari 2017 di Kemukiman Lambaro Angan Kabupaten Aceh Besar. Analisa data dilakukan menggunakan komputer dengan uji statistik Chi-square $\left(\mathrm{x}^{2}\right)$ dengan $\alpha=0.05$.Kesimpulanterdapat hubungan antara pendidikan, pendapatan dan sosial budaya dengan pernikahan dini.
\end{abstract}

Kata kunci: pendidikan, pendapatan, sosial budaya, pernikahan dini

\begin{abstract}
The number of cases of early marriage in Indonesia reached 50 million people with an average age of marriage was 19.1 years. One-third of the number of marriages recorded by couples under the age of 16 years. Data from KUA Lambaro Angan Aceh Besar in 2016 of 120 married couples, with 24 (20\%) of couples who married early. To determine the factors that influence young women perform early marriage in Kemukiman Lambaro Angan Aceh Besar district. This study is cross-sectional analytic approach. The samples consists of 68 people with stratisfied random sampling technique. The data was collected by distributing questionnaires to couples who have married within the period from November 2016 to January 2017 in Kemukiman Lambaro Angan Aceh Besar district. Data analysis was done using a computer with a statistical test Chi - square (x2) with $\alpha=0.05$ level. Conclusion : there is a relationship between education, income and social culture of the early marriage.
\end{abstract}

Keywords : education, income, socio- cultural, early marriage 


\section{PENDAHULUAN}

Menikah di usia kurang dari 18 tahun merupakan realita yang harus dihadapi sebagian remaja di seluruh dunia, terutama negara berkembang. Meskipun Deklarasi Hak Azasi Manusia di tahun 1954 secara eksplisit menentang pernikahan dini, namun ironisnya praktek usia pernikahan usia dini masih berlangsung di berbagai belahan dunia dan hal ini merefleksikan perlindungan hak azasi usia muda yang terabaikan. Implementasi UndangUndangpun seringkali tidak efektif dan terpatahkan oleh adat istiadat serta tradisi yang mengatur norma sosial suatu kelompok masyarakat (Pambudy, 2008).

Suatu studi literasi UNICEF (2006) menemukan bahwa interaksi berbagai faktor menyebabkan remaja berisiko menghadapi pernikahan usia dini. Diketahui secara luas bahwa pernikahan remaja berkaitan dengan tradisi dan budaya, sehingga sulit untuk mengubah. Alasan ekonomi, harapan mencapai keamanan sosial dan finansial setelah menikah menyebabkan banyak orang tua terdorong untuk menikahkan anaknya di usia muda.

Praktek pernikahan usia dini paling banyak terjadi di Afrika dan Asia Tenggara. Di Asia Tenggara didapatkan data bahwa sekitar 10 juta anak usia di bawah 18 tahun telah menikah. Di Amerika Latin dan Karibia, 29\% wanita muda menikah saat mereka berusia 18 tahun. Prevalensi tinggi kasus pernikahan dini tercatat di Nigeria (79\%), Kongo (74\%), Afganistan (54\%), dan Bangladesh (51\%). Secara umum, pernikahan dini lebih sering terjadi pada remaja perempuan dibandingkan remaja laki-laki, sekitar 5\% remaja laki-laki menikah sebelum mereka berusia 19 tahun. Selain itu didapatkan pula bahwa remaja perempuan tiga kali lebih banyak menikah dini dibandingkan laki-laki (USAID, 2006).

Analisis survey penduduk antar sensus (SUPAS) 2015 dari Badan Koordinasi Keluarga Berencana Nasional (BKKBN) didapatkan angka pernikahan di perkotaan lebih rendah dibandingkan di pedesaan, untuk kelompok umur 15-19 tahun perbedaannya cukup tinggi yaitu $5.28 \%$ di pedesaan dan 11.88 di perkotaan. Hal ini menunjukkan bahwa wanita usia muda di pedesaan lebih banyak melakukan pernikahan usia dini.

Masyarakat pedesaan perkawinan usia dini terutama terjadi pada golongan ekonomi menengah ke bawah yang merupakan bentuk sosial pada pembagian peran dan tanggung jawab dari keluarga perempuan pada suami. Di masyarakat perkotaan, pernikahan usia dini umumnya terjadi karena kecelakaan (married by accident) akibat salah pergaulan yang terjadi pada remaja (Noorkasiani, 2009). 
Berdasarkan Survei Data Kependudukan Indonesia (SDKI) 2013, di beberapa daerah didapatkan bahwa sepertiga dari jumlah pernikahan terdata dilakukan oleh pasangan usia di bawah 16 tahun. Jumlah kasus pernikahan dini di Indonesia mancapai 50 juta penduduk dengan rata-rata usia perkawinan 19.1 tahun. Di Jawa Timur, Kalimantan Selatan, Jambi dan Jawa barat, angka kejadian pernikahan dini berturut-turut adalah 39.4\%, 35.5\%, 30.6\% dan 36.0\%. Bahkan di sejumlah pedesaan, pernikahan seringkali dilakukan segera setelah anak perempuan mendapat haid pertama.

Syariat islam tidak menetapkan batasan usia untuk kawin. Sebenarnya dengan bermacam-macamnya keadaan iklim di dunia, masing-masing negara tidak sama, sampai usia berapakah idealnya seorang menikah. Tetapi dalam AI-Qur'an diterangkan bahwa batas usia untuk kawin ialah setelah mencapai usia dewasa. Jadi terang sekali bahwa cukup umur untuk kawin dan telah cerdas (dewasa akalnya) itu sama saja usia dewasa (Surtiretna, 2001).

Faedah yang terbesar dalam pernikahan ialah untuk menjaga dan memelihara kerukunan anak cucu (keturunan), nikah juga dipandang sebagai kemaslahatan umum sebab kalau tidak ada pernikahan. tentu manusia akan menurutkan sifat kebinatangan dan dengan sifat itu akan timbul perselisihan, bencana permusuhan sampai menimbulkan pembunuhan yang maha dasyat (Rasjid, 2002).

Kawin di usia muda mungkin bukan pilihan terbaik tapi bisa dijadikan alternatif mengatasi pergaulan bebas. Namun, kehadiran makhluk lain dalam perkawinan tersebut sebaiknya ditunda dulu. Masalah perkawinan usia dini biasanya rawan konflik, resiko kematian melahirkan bagi perempuan remaja juga masih tinggi. Selain itu pernikahan usia dini juga memberi risiko yang lebih besar pada remaja perempuan khususnya pada aspek reproduksinya. Pernikahan usia dini jugaakan berimplikasi pada keterbelakangan pengetahuan akibat terhambatnya proses pendidikan disebabkan pernikahan tersebut. Aspek sosial buda masyarakat member pengaruh terhadap pelaksanaan pernikahan usia dini (Bruce, 2007).

Menurut Badan Koordinasi Keluarga Berencana Nasional (BKKBN) usia untuk hamil dan melahirkan adalah 20 sampai 30 tahun, lebih atau kurang dari usia tersebut adalah berisiko. Kesiapan seorang perempuan untuk hamil dan melahirkan atau mempunyai anak ditentukan oleh kesiapan dalam tiga hal, yaitu kesiapan fisik, kesiapan mental/ emosi/ psikologis dan kesiapan sosial/ ekonomi. Secara umum, seorang perempuan dikatakan siap secara fisik jika telah menyelesaikan pertumbuhan tubuhnya (ketika tubuhnya berhenti 
tumbuh), yaitu sekitar usia 20 tahun. Sehingga usia 20 tahun bisa dijadikan pedoman kesiapan fisik (BKKBN, 2005).

Perkawinan remaja sering terjadi pada anak perempuan yang tingkat pendidikan rendah. Pendidikan anak perempuan berpengaruhi terhadap tradisi perkawinan remaja (dini) dimana bila seseorang anak perempuan mempunyai pendidikan yang lebih rendah kemungkinan terjadinya perkawinan remaja lebih besar dibandingkan dengan anak perempuan yang berpendidikan tinggi. Pada sisi lain di daerah yang menganggap anak perempuan sebagai beban ekonomi bagi keluarga sehingga mendorong orang tua untuk secepatnya bebas dari beban tersebut.Perkawinan remaja yang umumnya lebih banyak ditemukan didaerah pedesaan dari pada perkotaan, mencerminkan hubungan yang lebih erat dengan tradisi masyarakat terpencil. Penyebabnya berkaitan erat dengan pandangan masyarakat tentang wanita ideal. Di daerah yang menganggap fungsi utama seorang wanita adalah sebagai istri dan ibu rumah tangga akan lebih bermanfaat jika wanita mengembangkan kepribadiannya, menyesuaikan diri dengan suami dan keluarganya sedini mungkin (Royston, 2000).

Penyebab pernikahan dini menurut Choa (2001) dan Sibagariang (2010) adalah pendidikan remaja yang rendah, tekanan ekonomi, faktor sosial budaya dan modernisasi. Persoalan ekonomi keluarga, orang tua menganggap jika anak gadisnya telah ada yang melamar dan mengajak menikah, setidaknya ia diharapkan akan mandiri tidak lagi bergantung kepada orang tua, karena sudah ada suami yang siap menafkahi. Sekalipun, usia anak perempuannya belum mencapai kematangan, baik secara fisik maupun mental. Sayangnya, para gadis ini juga menikah dengan pria berstatus ekonomi tak jauh beda, sehingga malah menimbulkan kemiskinan baru. Karena pergaulan dan lingkungan masih ada pula perkawinan usia muda yang terjadi karena hamil dimasa pacaran.

Berdasarkan data dari Kantor Urusan Agama (KUA) Kabupaten Aceh Besar tahun 2016-2017 didapatkan jumlah wanita yang kawin di usia muda sebanyak 54 orang dari 264 orang wanita yang kawin. Jumlah wanita yang kawin diusia muda tersebut pada umumnya dengan status pendidikan pelajar.

Menurut data dari KUA lambaro Angan Kecamatan Darussalam Kabupaten Aceh Besar tahun 2014 dari 118 orang pasangan yang menikah dan tercatat $23(19,50 \%)$ orang pasangan yang menikah muda. Pada tahun 2015 dari 120 orang pasangan yang menikah, tercatat 24 (20\%) orang pasangan yang menikah muda. Pada tahun 2016 dari 120 orang pasangan yang menikah, tercatat 31 (25\%) orang pasangan yang menikah muda. Dan pada bulan November 
2016 sampai Januari 2017 tercatat dari 87 orang pasangan yang menikah, tercatat 26 pasangan $(29.8 \%)$ menikah muda.

Berdasarkan uraian diatas maka perlu dilakukan penelitian " Faktor-Faktor Yang Mempengaruhi Remaja Putri Melakukan Pernikahan Dini Di Kemukiman Lambaro Angan Kabupaten Aceh Besar Tahun 2017".

\section{METODE PENELITIAN}

Penelitian ini merupakan penelitian analitik dengan desain penelitian cross sectional. Penelitian ini dilakukan di Kemukiman Lambaro Angan Kabupaten Aceh Besar pada tanggal 18-22 Januari 2017 yaitu dengan total populasi pasangan yang menikah periode November 2016 sampai Januari 2017 yaitu sebanyak 207 pasangan.

\section{HASIL DAN PEMBAHASAN}

Berdasarkan penelitian yang dilaksanakan pada 18-22 Januari 2017 yaitu dengan total populasi pasangan yang menikah periode November 2016 sampai Januari 2017 yaitu sebanyak 207 pasangan, responden sebanyak 26 responden (38.2\%) menikah pada usia dini yaitu dibawah 20 tahun, sedangkan 42 responden (61.8\%) menikah di atas usia 20 tahun.

Analisis bivariat menggunakan uji chi_square yang bertujuan untuk mengetahui hubungan variabel pendidikan, pendapatan, sosial budaya dengan pernikahan dini. Hasil analisis bivariat tersebut disajikan pada tabel 1. sebagai berikut:

Tabel 1. Hasil Analisis Bivariat Hubungan Pendidikan, Pendapatan dan Sosial Budaya dengan Pernikahan Dini di Kemukiman Lambaro Angan Kabupaten Aceh Besar tahun 2017

\begin{tabular}{|c|c|c|c|c|c|c|c|}
\hline \multirow{2}{*}{ Variabel Independen } & \multicolumn{4}{|c|}{ Pernikahan Dini } & \multicolumn{2}{|c|}{ Total } & \multirow{2}{*}{$\begin{array}{c}\text { P- } \\
\text { Value }\end{array}$} \\
\hline & Ya & $\%$ & Tidak & $\%$ & f & $\%$ & \\
\hline \multicolumn{8}{|l|}{ Pendidikan } \\
\hline 1. Dasar & 16 & 55.2 & 13 & 44.8 & 29 & & \multirow{3}{*}{0.045} \\
\hline 2. Menengah & 6 & 24.0 & 19 & 76.0 & 25 & 100 & \\
\hline 3. Tinggi & 4 & 28.6 & 10 & 71.4 & 14 & 100 & \\
\hline \multicolumn{8}{|l|}{ Pendapatan } \\
\hline 1. Tinggi & 8 & 22.2 & 28 & 77.8 & 36 & 100 & \multirow[b]{2}{*}{0.008} \\
\hline 2. Rendah & 18 & 56.2 & 14 & 43.8 & 32 & 100 & \\
\hline \multicolumn{8}{|l|}{ Sosial Budaya } \\
\hline 1. $\mathrm{Ya}$ & 17 & 58.6 & 12 & 41.4 & 29 & 100 & \multirow[t]{2}{*}{0.006} \\
\hline 2. Tidak & 9 & 23.1 & 30 & 76.9 & 39 & 100 & \\
\hline
\end{tabular}




\section{Pembahasan}

1. Hubungan Pendidikan denganPernikahan Dini di Kemukiman Lambaro Angan Kabupaten Aceh Besar tahun 2017

Hasil uji statistik dengan menggunakan uji chi-square menunjukkan perbedaan presentase tersebut bermakna yaitu dengan nilai $\mathrm{p}=0.045$ artinya terdapat hubungan bermakna antara pendidikan dengan pernikahan dini di Kemukiman Lambaro Angan Kabupaten Aceh Besar tahun 2017.

Hasil analisis hubungan terlihatbahwa responden yang melakukan pernikahan usia dini lebih banyak dijumpai pada responden yang berpendidikan dasar yaitu 16 orang (55.2\%) dibandingkan responden yang berpendidikan tinggi yaitu 4 orang (28.6\%) dan responden yang berpendidikan menengah yaitu 6 orang $(24.0 \%)$.

Penelitian ini sesuai dengan penelitian yang dilakukan Sari (2009) tentang faktor yang berhubungan dengan pernikahan dini yaitu terdapat hubungan sangat bermakna antara pendidikan dengan pernikahan dini, diperoleh nilai $\mathrm{p}=0.000$. responden yang memiliki tingkat pendidikan rendah cenderung menikah dini.

Hasil penelitian yang sama dilakukan Marieyam (2011) tentang Hubungan Pendidikan dengan Pelaksanaan Perkawinan Usia Dini Setelah Berlakunya UndangUndang No 1 Tahun 1974 Tentang Perkawinan, diperoleh hasil terdapat hubungan yang bermakna antara Pendidikan dengan Pelaksanaan Perkawinan Usia Dini Setelah Berlakunya Undang-Undang No 1 Tahun 1974 Tentang Perkawinan, dimana nilai p=0,004. Hal ini dikarenakan karena masih banyak remaja yang mempunyai pendidikan rata-rata SD-SMP, sehingga informasi dan pemahaman yang dimiliki terutama tentang perilaku seksual pranikah berkurang atau tidak mengetahui sama sekali.

Pada beberapa studi sosial terdapat sebuah teori yang menyatakan bahwa semakin tinggi pendidikan perempuan, maka semakin lama usia pernikahan pertamanya. Yustiana (2008) menyebutkan bahwa perempuan yang memiliki pendidikan tinggi memperlihatkan kurangnya minat untuk menikah. Perempuan yang masih berada dalam sebuah institusi pendidikan cenderung untuk menikah seusai sekolah, sehingga institusi membuat perempuan menikah di usia lanjut.

Pernikahan anak dan derajat pendidikan semakin muda usia menikah, maka semakin rendah tingkat pendidikan yang dicapai oleh sang anak. Pernikahan anak seringkali menyebabkan anak tidak lagi bersekolah, karena kini ia mempunyai tanggungjawab baru, 
yaitu sebagai istri dan calon ibu, atau kepala keluarga dan calon ayah, yang diharapkan berperan lebih banyak mengurus rumah tangga maupun menjadi tulang punggung keluarga dan keharusan mencari nafkah. Pola lainnya yaitu karena biaya pendidikan yang tak terjangkau, anak berhenti sekolah dan kemudian dinikahkan untuk mengalihkan beban tanggungjawab orangtua menghidupi anak tersebut kepada pasangannya (Saputro, 2006).

Berbagai penelitian didapatkan bahwa terdapat korelasi antara tingkat pendidikan dan usia saat menikah, semakin tinggi usia anak saat menikah maka pendidikan anak relatif lebih tinggi dan demikian pula sebaliknya. Pernikahan di usia dini menurut penelitian UNICEF tahun 2006 tampaknya berhubungan pula dengan derajat pendidikan yang rendah. Menunda usia pernikahan merupakan salah satu cara agar anak dapat mengenyam pendidikan lebih tinggi.

Asumsi peneliti, maraknya pernikahan dini di Kemukiman Lambaro Angan disebabkan oleh tingkat pendidikan yang rendah, dikarenakan ketidakmampuan untuk melanjutkan pendidikan yang membuat para orang tua menikahkan anaknya pada usia muda. Jika seseorang perempuan tidak mendapatkan pendidikan maka perempuan tidak memiliki aktifitas sehingga dijadikan alasan para orangtua untuk mengawinkan anak mereka. Sebaliknya apabila seorang perempuan mendapatkan pendidikan yang baik maka perempuan akan terfokus pada aktivitasnya dibandingkan dengan menikah atau berkeluarga. Maka dari itu pendidikanlah yang membuat perempuan di daerah perkotaan cenderung menikah lebih lambat dibandingkan dengan perempuan di pedesaan.

2. Hubungan Pendapatan denganPernikahan Dini di Kemukiman Lambaro Angan Kabupaten Aceh Besar tahun 2017

Berdasarkan uji statistik dengan menggunakan uji chi-square menunjukkan perbedaan presentase tersebut bermakna yaitu dengan nilai $\mathrm{p}=0.008$, artinya ada hubungan bermakna antara pendapatan dengan pernikahan dini di Kemukiman Lambaro Angan Kabupaten Aceh Besar tahun 2017.

Hasil analisis hubungan terlihat bahwa responden yang menikah dini lebih banyak dijumpai pada pasangan yang pendapatan orangtuanya dalam kategori rendah yaitu sebanyak 18 orang $(56.2 \%)$ dibandingkan dengan pendapatan orangtua kategori tinggi yaitu 8 orang $(22.2 \%)$. 
Pernikahan anak merupakan masalah sosial dan ekonomi, yang diperumit dengan tradisi dan budaya dalam kelompok masyarakat. Stigma sosial mengenai pernikahan setelah melewati masa pubertas yang dianggap aib pada kalangan tertentu, meningkatkan pula angka kejadian pernikahan anak (UNICEF, 2006).

Faktor ekonomi seseorang dapat merupakan salah satu faktor penyebab terjadinya perkawinan dibawah umur. Keadaan ekonomi yang dimaksud adalah meliputi keadaan ekonomi keluarga yang sudah mapan atau mampu maupun keadaan ekonomi keluarga yang belum mapan atau kurang mampu. Adapun untuk keluarga yang keadaan ekonominya belum mapan atau kurang mampu sementara anaknya banyak, maka biasanya anak yang terbesar meskipun belum mencapai usia yang cukup untuk kawin segera dikawinkan oleh orang tuanya dengan maksud agar beban yang ditanggung oleh keluarga tersebut segera berkurang. Bahkan itu datangnya tidak hanya dari pihak orang tua saja melainkan juga dari keinginan anak yang bersangkutan setelah ia melihat keadaan keluarganya yang memprihatinkan (Achmad, 2005).

Motif ekonomi, harapan tercapainya keamanan sosial dan finansial setelah menikah menyebabkan banyak orangtua menyetujui pernikahan usia dini. Alasan orangtua menyetujui pernikahan anak ini seringkali dilandasi pula oleh ketakutan akan terjadinya kehamilan di luar nikah akibat pergaulan bebas atau untuk mempererat tali kekeluargaan.Secara umum, pernikahan anak lebih sering dijumpai di kalangan keluarga miskin, meskipun terjadi pula di kalangan keluarga ekonomi atas (Qorni, 2002).

Banyak negara, pernikahan anak seringkali terkait dengan kemiskinan. Negara dengan kasus pernikahan anak, pada umumnya mempunyai produk domestik bruto yang rendah.Pernikahan anak membuat keluarga, masyarakat, bahkan negara mengalami kesulitan untuk melepaskan diri dari jerat kemiskinan dan hal ini tentunya menyebabkan kualitas kesehatan dan kesejahteraan yang rendah baik anak maupun keluarga dan lingkungannya. Selain itu terjadinya pernikahan dini pada remaja disebabkan oleh faktor ekonomi yang dialami keluarga, umumnya terjadi pada masyarakat yang tergolong menengah ke bawah, yang berawal dari ketidakmampuan mereka melanjutkan pendidikan mereka ke jenjang yang lebih tinggi. Terkadang remaja hanya bisa melanjutkan sampai sekolah menengah saja atau bahkan tidak bisa mengenyam sedikitpun kenikmatan pendidikan, sehingga menikah menjadi sebuah solusi dari kesulitan yang mereka hadapi. Terutama remaja putri di tengah kondisi ekonomi mereka yang sulit, para orangtua lebih 
memilih mengantarkan putri mereka untuk menikah, karena paling tidak sedikit banyak beban mereka akan berkurang, tetapi pada remaja putra sedikit terjadi karena peran lakilaki dalam kehidupan berumah tangga sangatlah besar, sehingga bagi kaum adam minimal harus mempunyai ketrampilan terlebih dahulu sebagai modal awal membangun rumah tangga mereka (Adhim, 2010).

Asumsi peneliti, penyebab pernikahan dini di Kemukiman Lambaro Angan ditinjau dari segi pendapatan, yaitu rendahnya pendapatan yang diperoleh orangtua sehingga mereka mengganggap dengan menikahkan anaknya maka beban orangtua menjadi berkurang. Disamping itu anak perempuan mereka juga tidak melanjutkan pendidikan sehingga alasan untuk menikahkan anak di usia dini juga diperkuat. Para orangtua juga memiliki harapan agar kehidupan anaknya kelak menjadi mapan, meskipun kenyataannya tingkat ekonomi suami tidak jauh berbeda dengan orangtua perempuan tersebut. Hal inilah yang menyebabkan pernikahan usia muda meningkatkan angka kemiskinan di Indonesia.

3. Hubungan Sosial Budaya dengan Pernikahan Dini di Kemukiman Lambaro Angan Kabupaten Aceh Besar tahun 2017

Berdasarkan uji statistik dengan menggunakan uji chi-square menunjukkan perbedaan presentase tersebut bermakna yaitu dengan nilai $\mathrm{p}=0.006$, artinya ada hubungan bermakna antara sosial budaya dengan pernikahan dini di Kemukiman Lambaro Angan Kabupaten Aceh Besar tahun 2017.

Hasil analisis hubungan terlihat bahwa responden yang menikah dini lebih banyak dijumpai pada responden yang memiliki pengaruh sosial budaya yaitu 17 orang (58.6\%) dibandingkan dengan responden yang tidak memiliki pengaruh budaya yaitu 9 orang $(23.1 \%)$.

Faktor budaya juga turut mengambil andil yang cukup besar, karena kebudayaan ini diturunkan dan sudah mengakar layaknya kepercayaan. Dalam budaya setempat mempercayai apabila anak perempuannya tidak segera menikah, itu akan memalukan keluarga karena dianggap tidak laku dalam lingkungannya. Atau jika ada orang yang secara finansial dianggap sangat mampu dan meminang anak mereka, dengan tidak memandang usia atau status pernikahan, kebanyakan orang tua menerima pinangan tersebut karena beranggapan masa depan sang anak akan lebih cerah, dan tentu saja ia 
diharapkan bisa mengurangi beban sang orang tua. Tak lepas dari hal tersebut, tentu saja banyak dampak yang tidak terpikir oleh mereka sebelumnya (Nasution, 2006).

Menurut Hadi Supeno, adanya tradisi lama yang sudah turun temurun yang menganggap perkawinan pada usia anak-anak sebagai suatu hal yang wajar. Dalam masyarakat Indonesia, bila anak gadisnya tidak segera memperoleh jodoh, orang tua merasa malu karena anak gadisnya belum menikah. Budaya eksploitatif terhadap anak, yang membuat anak tidak berdaya menghadapi kehendak orang dewasa, baik orang tuanya yang menginginkan perkawinan itu, maupun orang yang mengawini.

Mengeksploitasi anak atas nama ekonomi atau materi, ada yang karena gengsi atau harga diri bisa mengawinkan anaknya dengan orang yang dianggap terpandang tanpa memperdulikan apakah calon suami anaknya sudah beristri atau belum, apakah anak perempuannya sudah siap secara fisik, mental dan sosial ataukah belum. Ada yang mengeksploitasi anak karena mental hedonis, mencari kesenangan pada banyak hal termasuk poligami dengan anak-anak di bawah umur. Alasan lain bahkan mengeksploitasi anak atas nama agama, walaupun banyak tokoh agama telah tegas menyatakan bahwa perkawinan pada usia anak bukanlah ajaran agama, terutama apabila diklaim sebagai bagian dari sunah Nabi SAW (Thayib, 2004).

Menikah di usia kurang dari 18 tahun merupakan realita yang harus dihadapi sebagian anak di seluruh dunia, terutama negara berkembang. Meskipun Deklarasi Hak Asasi Manusia di tahun 1954 secara eksplisit menentang pernikahan anak, namun ironisnya, praktek pernikahan usia dini masih berlangsung di berbagai belahan dunia dan hal ini merefleksikan perlindungan hak asasi kelompok usia muda yang terabaikan. Implementasi Undang-Undangpun seringkali tidak efektif dan terpatahkan oleh adat istiadat serta tradisi yang mengatur norma sosial suatu kelompok masyarakat. Suatu studi literasi UNICEF menemukan bahwa interaksi berbagai faktor menyebabkan anak berisiko menghadapi pernikahan di usia dini. Diketahui secara luas bahwa pernikahan anak berkaitan dengan tradisi dan budaya, sehingga sulit untuk mengubah (UNICEF, 2006).

Asumsi peneliti, pernikahan usia dini sebagai bentuk perilaku yang sudah dapat dikatakan membudaya dalam masyarakat di Indonesia. Maksudnya bahwa batasan individu dengan meninjau kesiapan dan kematangan usia individu bukan menjadi penghalang bagi seseorang untuk tetap melangsungkan pernikahan. Masyarakat cenderung berpikir apabila mempunyai anak perempuan tanpa memandang matang atau tidaknya umur, para orangtua 
segera berpikir untuk menikahkan anaknya. Sementara, pada masyarakat di Kemukiman Lambaro Angan, pernikahan yang terjadi pada usia dini lebih dikarenakan adanya dorongan rasa kemandirian dari perempuan dan untuk melepaskan diri dari pengaruh orang tua serta melihat fenomena lingkungan sekitar yang sebagian teman sebaya mereka telah menikah di usia seperti mereka. Sehingga adanya kecenderungan terpengaruh oleh lingkungan sekitar untuk menikah di usia muda. Pengaruh sosial budaya yang dialami para orang tua di Kemukiman Lambaro Angan meliputi seperti adanya perasaan malu dan minder yang dirasakan para orangtua apabila saat umur anaknya menginjak di atas 20 tahun anak perempuannya tersebut belum menikah. Sehingga para orang tua dengan mudahnya mengawinkan anak mereka di bawah usia 20 tahun dengan pemuda yang melamar tanpa memperhatikan kematangan dari sisi finansial pemuda tersebut. Dan apabila dikaji alasan tersebut tidaklah mendasar disebabkan para pemuda yang melamar anak perempuan mereka sebagian kecil saja yang memiliki penghasilan tetap, kebanyakan dari para pemuda tersebut bekerja tidak tetap sehingga hal demikianlah yang menyebabkan maraknya angka kemiskinan di Propinsi Aceh.

\section{KESIMPULAN}

Terdapat hubungan bermakna antara pendidikan dengan pernikahan dini pada pasangan di kemukiman Lambaro Angan Kabupaten Aceh Besar, dengan nilai $\mathrm{p}=0.045$ ( $\mathrm{p}<$ 0.05), terdapat hubungan bermakna antara pendapatan dengan pernikahan dini pada pasangan di kemukiman Lambaro Angan Kabupaten Aceh Besar, dengan nilai p = 0.008 ( $<$ < 0.05) dan terdapat hubungan bermakna antara Sosial Budaya dengan pernikahan dini pada pasangan di kemukiman Lambaro Angan Kabupaten Aceh Besar, dengan nilai p = 0.006 ( $\mathrm{p}<0.05)$.

\section{SARAN}

KepadaKepala Puskesmas Lambaro Angan Kecamatan Aceh Besar untuk mengadakan penyuluhan terhadap dampak yang mungkin timbul untuk melaksanakan Perkawinan Usia Muda. Di jaman modern seperti sekarang ini. Penyuluhan-penyuluhan tersebut dapat dilaksanakan melalui seminar, kursus-kursus dan atau sosialisasi keberbagai kalangan masyarakat, sehingga dapat memberi pelayanan kepada masyarakat secara efektif. Guna meminimalisasikan terjadinya perkawinan usia muda yang sering terjadi akhir-akhir ini. Perkawinan Usia Muda akan banyak menimbulkan permasalahan-permasalahan dikemudian 
hari yang sangat perlu diperhatikan, oleh karena itu perlunya dukungan dari berbagai pihak untuk memberikan perhatian-perhatian yang lebih terhadap perkembangan moralitas bangsa Indonesia. Dan dapat mengadakan kegiatan-kegiatan sosial di lingkungan masyarakat, seperti Karang Taruna dan Remaja Mesjid. Sehingga dapat membantu manambah pengetahuan dan juga pengerem bagi remaja dalam melakukan kegiatan-kegiatan yang negatif. Sehingga dapat tersalurkan baik hobi dengan kegiatan yang menyenangkan, agar keinginan menikah muda dapat tertunda sampai sudah cukup umur menurut Undang-Undang Pernikahan.

\section{DAFTAR PUSTAKA}

Achmad, M. (2005). Psikologi Keluarga, dari keluarga Sakinah hingga Keluarga Bangsa. Jakarta: PT. Bina Rena Pariwara.

Adhim, M. (2010). Indahnya Pernikahan Dini. Jakarta: Gema Insani Press.

BKKBN. (2008). Kehamilan Remaja. BKKBN. Jakarta.

BKKBN. (2012). Pernikahan Dini Pada Beberapa Provinsi Di Indonesia. BKKBN. Jakarta.

Bruce, J. (2007). Child Marriage in The Context of the HIV epidemic. Brief Journal.

Choa. (2001). Perkawinan Usia Muda dan Dampaknya terhadap Keutuhan Rumah Tangga: Studi di Kecamatan Dawar Blandong Kabupaten Mojokerto. Skripsi tidak diterbitkan. Surabaya: Program Sarjana Universitas Negeri Surabaya.

Depkes, RI. (2001). Pedoman Pemantauan Wilayah Setempat Kesehatan Ibu dan Anak (PWSKIA). Jakarta.

Dianawati, Ajen. (2003). Pendidikan Seks Untuk Remaja. Kawan Pustaka. Jakarta.

Eddy, F. (2009). Hubungan Tingkat Pendidikan dan Sosial Budaya Masyarakat terhadap terjadinya Pernikahan Usia Dini di Keluahan Segarsari Kecamatan Lembang Bandung.

Gunansa. (2008). Psikologi Remaja: Petunjuk bagi Orangtua dan Guru. Bandung: Pustaka Setia.

Haditono, Siti Rahayu Dkk. (2002). Psikologi Perkembangan. Gadjah Mada Universiy Press. Yogyakarta.

Hastono, S. P. (2006). Basic Data Analysis for Health Research. Universitas Indonesia (UI): Fakultas Kesehatan Masyarakat.

Ihsan, Fuad. (2008). Dasar-Dasar Pendidikan. Rineka Cipta. Jakarta.

Juspin, L. (2009). Studi Kasus Kebiasaan Pernikahan Usia Dini pada Masyarakat Kecamatan Sanggalangi Kabupaten Tana Toraja.

Kantor Urusan Agama. (2012). Data Jumla Pasangan yang Menikah di Kemukiman Lambaro Angan peiode 2010-2011.

Kusmiran, E. (2012). Reproduksi Remaja dan Wanita.Jakarta: Salemba Medika. 
Kumalasari, Intan dkk. (2012). Kesehatan Reproduksi Untuk Mahasiswa Kebidanan Dan Keperawatan. Salemba Medika. Jakarta

Kusmiran, Eny. (2012). Kesehatan reproduksi Remaja Dan Wanita. Salemba Medika. Jakarta.

Marieyam. (2011). Hubungan Pendidikan dengan Pelaksanaan Perkawinan Usia Dini setelah Berlakunya Undang-Undang No 1 tahun 1974 tentang Perkawinan.

Maryunani, (2010). Ilmu Kesehatan Anak dalam Kebidanan. Jakarta: Salemba Medika.

Nasution, H. (2006). Membina Keluarga Bahagia, Jakarta: PT.Pustaka Antara.

Novita, Nesi. (2011). Promosi Kesehatan Dalam Pelayanan Kebidanan. Salemba Medika. Jakarta

Noorkasiani, Dkk. (2009). Sosiologi Keperawatan. EGC. Jakarta

Pambudy MN. (2009). Perkawinan Anak Melanggar Undang-Undang Perkawinan. Diunduh tanggal 14 Juli 2013. Didapat dari http://cetak.kompas.com/read.

Qorni, M. (2002). Indahnya, Manisnya Bercinta Setelah Menikah. Jakarta: Mustaqim.

Rasjid, S. (2002). Fiqh Islam. PT, Sinar Baru Algensindo. Bandung.

Royston, E. (2000). Pencegahan Kematian Ibu Hamil. Binarupa Aksara.

Sari. (2009). Faktor yang Berhubungan dengan Pernikahan Dini di Kelurahan Ciputat, Jakarta. Journal Universitas Indonesia.

Saputro, (2006). Pernikahan Anak dan Permasalahannya. Semarang: Bakti Pustaka.

Sarwono. S.W. (2011). Psikologi Remaja. Jakarta: PT Raja Grafindo Persada.

Sibagariang, E. (2010). Kesehatan Reproduksi Wanita. Jakarta: TIM.

Suhardjo. (2003). Perencanaan Pangan dan Gizi. Bumi Aksara. Jakarta. Diakses pada tanggal 8 Juli 2013. http://www.scribd.com/gizi3.

Survei Data Kependudukan Indonesia (SDKI). (2007). Jumlah pernikahan dini di beberapa daerah. Di akses dari http://lampung.tribunnews.com/2013/04/29/yang-muda-harusberencana.

Soeparan, Setiawan. (2006). Modul Mahasiswa Kesehatan Reproduksi. Kepala Pusat Pendidikan Tenaga Kesehatan. Jakarta

Sumiati dkk. (2009). Kesehatan jiwa Remaja Dan Konseling. TIM. Jakarta

Surtiretna, N. (2001). Bandung Seks Bagi Remaja. PT. Remaja Rosdakarya Bandung

Tanjung, Armaidi. (2007). Free Sex Nikah Yes. Amzah. Jakarta.

Thayib, A. (2004). Struktur Rumah tangga Muslim, Surabaya: PT. Risalah Gusti.

NICEF. (2006). Early Marriege: a harmful traditional practice. A statistical exploration. Diunduh tanggal 12 Juni 2013. Didapat dari: www.unicef.org.

USAID. (2006). Preventing child marriage: protecting girls health. [diunduh 29 Julil 2013]. Didapat dari: www.usaid.gov. 2006. 
Journal of Healthcare Technology and Medicine Vol. 3 No. 2 Oktober 2017

Universitas Ubudiyah Indonesia

e-ISSN : 2615-109X

Yamin. (2012). Traditions Limits Girls Future. Diunduh tanggal 14 Juni 2013. Didapat dari http://www.hartford-hwp.com.

Yustiana, H. (2008). Pengalaman Belajar Awal yang Bermakna bagi Anak melalui Aktivitas Bermain. Tesis. Bandung. 